\title{
Watershield (Brasenia schreberi J. F. Gmel.), from Popular Vegetable to Endangered Species
}

\author{
Changfang ZHOU* and Zhaozhao ZHONG \\ School of Life Sciences, Nanjing University, Nanjing, China
}

\begin{abstract}
*Corresponding author: Changfang ZHOU, School of Life Sciences, Nanjing University, 163\# Xianlin Avenue, Qixia District, Nanjing, China.
\end{abstract}

Received Date: February 16, 2021

Published Date: February 23, 2021

\begin{abstract}
Watershield (Brasenia schreberi J. F. Gmel.) is an aquatic vegetable which has been popular for more than a thousand years in China but become endangered species in recent years. It is characterized with a thick mucilage mainly composed of polysaccharides, which are believed to have both nutritional and medical values. The diminishing of watershield population in China may be caused by habitat loss, lagging cultivation and processing technology, and low genetic diversity of the species, etc. Interdisciplinary strategies and international cooperation are needed for the rejuvenation of the watershield industry.
\end{abstract}

Keywords: Aquatic vegetable; Cultivation; Endangered species; Watershield

\section{Introduction}

The watershield (Brasenia schreberi J.F. Gmel.), also known as Junsai in Japan, is a monotypic genus in the Nymphaeaceae family (listed in the Cabombaceae family in some references). It is a perennial floating-leaved macrophyte, with young buds being served as a popular aquatic vegetable in China, Japan and some other east Asian countries. The plant is characterized with a luxuriant but transparent mucilage, which coats all the submerged organs and especially young buds, and is mainly composed of polysaccharides, including D-galactose, D-glucose, L-rhamnose, L-fucose, D-mannose, D-xylose, L-arabinose and D-glucuronic acid [1,2]. It is reported that the mucilage of watershield has strong antioxidant capacity, and can enhance human immunity, reduce blood sugar and plasma cholesterol, etc. [3]. Besides, leaves of watershield have been found to be rich in zinc, which may prevent the occurrence of attention deficit hyperactivity disorder (ADHD) in children [4]. Hence, the plant has been highly valued for both nutritional and medical purposes.

\section{Distribution and Cultivation of Watershield}

Watershield widely distributes in tropical and temperate regions of East Asia, West Indies, North and Central America, South
Africa and Australia. Fossil Brasenia species was also reported in Europe which became extinct at the end of the last interglacial or at the beginning of the Weichselian glaciation [5]. However, it is only in east Asia, that young buds of the plants are harvested as a traditional vegetable.

In China, wild populations of watershield have been found in Jiangsu, Zhejiang, Fujian, Guangdong, Sichuan, Chongqing, Hubei, Hunan, Yunnan, Anhui, Jiangxi and Taiwan Provinces [6]. Large scale cultivation of watershield can be also found in Suzhou of Jiangsu and Hangzhou of Zhejiang in east China, as well as Lichuan of Hubei and Shizhu of Chongqing in central China.

Among them, Suzhou keeps the earliest record of watershield to be served as a popular aquatic vegetable, with a history for more than 1700 years when the local ancestors tried to search for the unique mucilage-coated buds of the species, which just sporadically distributed in the shallow zone of the Chinese third largest freshwater lake, Taihu Lake. There is no record showing when cultivation of the plants was exactly started, but only that it is well agreed such process in Suzhou has been prolonged for more than a thousand 
years [7]. Meanwhile, Suzhou once had the largest cultivation area as well as the biggest market of watershield in the country. Unfortunately, such cultivation has been dwindled during the past 30 years, with less than 60 ha remained by now. The situation of watershield in Hangzhou was similar to that of Suzhou, which was once popular along the Xihu Lake basin, but now reduced too.

Large scale cultivation of watershield now in China can only be found in central mountain area. The watershield cultivation in Lichuan started in1980es and now occupies an area about 2000 ha [8], that in Shizhu started in similar time and now has an area about 900 ha [9]. Here the local people make use of small pieces of flat lands in the mountain valleys to grow watershield. Such habitats are not ponding or lakes but fields, just like rice fields. Also, without rivers and lakes for irrigation, people here usually make use of the mountain streams to maintain the water level of the watershield field to be around $40 \mathrm{~cm}$. Such cultivation in Lichuan and Shizhu has a history for less than a half century, but the two areas now contribute to more than $90 \%$ of the watershield product of the whole country.

\section{Problems of the Watershield Industry in China}

Although the watershield cultivation in central China still maintain a relatively large area, the vegetable market mainly exists in east provinces, such situation significantly restricts the development of the watershield industry. It is necessary to make it clear that why the watershield cultivation in east China is dwindled. Here are some of the reasons.

\section{Habitat loss}

Watershield in Suzhou naturally grows in ponds or shallow basin of the Taihu Lake with water level around $1 \mathrm{~m}$, where we call wetlands. With human population increase and city expansion, large area of the low land has been occupied to build houses and factories. The remain shallow area are now widely used for aquaculture of crabs, shrimps or fishes which may bring higher incomes to the farmers. There was a period when the farmers in Dongshan, a town next to the Taihu Lake, turned almost all of their watershield ponds into crab fishery at the end of $1990 \mathrm{es}$, although the town had been famous with its watershield production for decades before that.

Besides the diminishing of wetland area is the deterioration of wetland quality. With excessive nitrogen and phosphorous loading from shallow lake fishery, upland agricultural runoff, industrial wastewater and daily life wastes, etc., the Taihu Lake has experienced serious eutrophication and cyanobacterial bloom bursts frequently [10]. However, our previous research has demonstrated that watershield requires good water quality and nutrient enriched sediments to accumulate its mucilage [11]. Poor water quality may threaten the survival of watershield population.

\section{Lagging cultivation and processing technology}

Although advanced technologies have been widely used in modern agriculture, new facilities have been only applied for the major food production like rice and wheat and some limited vegetable production on land. Ways to produce aquatic vegetables in the water changed little during the past decades. The farmers still have to collect the buds of watershield one by one by hand under the water, which is really hard work and few youngers would like to go on.

Storage of the watershield product is another challenge that need to be solved. As fresh watershield buds will decay within 3 days even under $4{ }^{\circ} \mathrm{C}$, the only practical way to store the buds for a longer time is to parboil for a couple minutes and then soak in weak acidic condition at $\mathrm{pH}=4$ [12]. However, such process also destroys part of the mucilage and affects the quality of the product, thus reduce the price in market.

\section{Low genetic diversity}

Studies have suggested that watershield in China has low genetic diversity, and higher variation was observed within populations rather than among populations $[6,13,14]$. It is relatively easy to be understood among the cultivars from the four major cultivation areas, as we have the historical records showing that the four places exchange their watershield germplasms frequently. Although watershield has been a popular aquatic vegetable in both Suzhou and Hangzhou for a long history, it doesn't mean that the two places should always keep the cultivations. They may cut off all the cultivars for several years and transplant them again in other years, and since the geographical distance between the two places is only about $120 \mathrm{~km}$, it is reasonable for the farmers to share their seedlings between each other. Other records also showed that Lichuan and Shizhu had transplanted seedlings from Suzhou in 1980es when the two areas first started their watershield industry.

Another reason for the low genetic diversity of watershield may exist in its own propagation property. Watershield have seeds, but the seedlings germinated from seeds are very weak, and the species mainly reproduce through its winter shoots or turions, which may result in the low genetic diversity.

In addition, although watershield has been found in quite a few provinces, their distributions are sporadical. Habitat fragmentation may also restrict the gene flow among wild populations of the species.

Besides the three choke points that have been listed, even more blockages on the watershield industry may exist. For example, we have recently noticed in an experiment that the decrease in temperature difference between day and night reduced the seed set of watershield. Potential influence of global warming on the species still needs to be explored.

\section{Conclusion}

Watershield is an important aquatic vegetable which has been popular for a long history but now in an awkward situation being severely diminishing, due to habitat loss, lagging cultivation and processing technology, low genetic diversity, etc. Effective efforts 
are required to protect the endangered species, not only for the rare aquatic vegetable market but also for the biodiversity of aquatic ecosystem. Currently, we are collecting wild watershield germplasms in China and try to breed more strains to counter the changing environments. Tissue culture and in-door facilitate cultivation of watershield are also attempted to solve the habitat deficiency [15]. Furthermore, modern technologies and especially interdisciplinary strategies are urgently needed to improve the cultivation of the vegetable. International cooperation between scientists from different continents where the watershield naturally distributes are also expected.

\section{Acknowledgement}

Our research of watershield has been supported by Jiangsu Independent Innovation Funding for Agricultural Science and Technology (CX (20) 2018) and Jiangsu Provincial Key Research and Development Program (BE2015357).

\section{Conflict of Interest}

No conflict of interest.

\section{References}

1. Kakuta M, Misaki A (1979) Polysaccharide of "Junsai (Brasenia schreberi J. F. Gmel)" mucilage: constitution and linkage analysis. Agric Biol Chem 43(5): 993-1005.

2. Feng S, Luan D, Ning K, Shao P, Sun P (2019) Ultrafiltration isolation, hypoglycemic activity analysis and structural characterization of polysaccharides from Brasenia schreberi. Int J Biol Macromol 135: 141151.

3. Wu H, Lv Z, Zhang Z, Yu J (2017) A comparative study of the commercially valuable components of water shield (Brasenia schreberi) from 4 cultivation areas in China. J Southwest Univ (Nat Sci Ed) 39(5): 76-82.
4. Li Y, Ke J, Jiao D, Peng Y, Yang B, et al. (2018) Research progress of nutritional value and application of Brasenia schreberi. J Changjiang Veget 18: 36-39.

5. Drzymulska D (2018) On the history of Brasenia Schreb. in the European Pleistocene. Veget Hist Archaeobot 27: 527-534.

6. Li ZZ, Gichira AW, Wang QF, Chen JM (2018) Genetic diversity and population structure of the endangered basal angiosperm Brasenia schreberi (Cabombaceae) in China. PeerJ 6: e5296.

7. Zhang C, Yan W, Li H, Yang D, Zhang Z, et al. (2017) Effects of different cultivation methods on quality and yield of Taihu Brasenia schreberi J. F. Gmel. Modern Agric Technol 11: 73-74.

8. Cai G, Liu X, Zhou F (2016) Reasons for the reduction of watershield in Lichuan and the strategy to solve the problem. J Changjiang Veget 17: 4-7.

9. Zhu S, Ke J, Li Y, Peng Y (2017) Problems of the watershield industry in Shizhu and relative strategy. South China Agric 11(31): 13-16.

10. Zhang Y, Yao X, Qin B (2016) Acritical review of the development, current hotspots, and future directions of Lake Taihu research from the bibliometrics perspective. Environ Sci Pollut Res 23: 12811-12821.

11. Xie C, Li J, Pan F, Fu J, Zhou W, et al. (2018) Environmental factors influencing mucilage accumulation of the endangered Brasenia schreberi in China. Sci Rep 8: 17955.

12. Liu X, Guo T, Xiao J, Zhang Y, Ma L (2012) Research progress for the storage of watershield. Food Eng 10: 111-113.

13. Zhang G, Gao B (2008) Analysis on genetic diversity and genetic structure of Brasenia schreberi in Jiangsu and Zhejiang Provinces revealed by ISSR markers. J Lake Sci 20(5): 662-668.

14. Liu C, Li X, Xu J, Shao K, Nie H, Ma G (2012) RAPD analysis of genetic diversity and phylogenetic relationships of Brasenia schreberi in three producing areas of China. J Southwest Univ (Nat Sci Ed) 34(10): 54-59.

15. Li J, Yi C, Zhang C, Pan F, Xie C, et al. (2021) Effects of light quality on leaf growth and photosynthetic fluorescence of Brasenia schreberi seedlings. Heliyon 7: e06082. 